
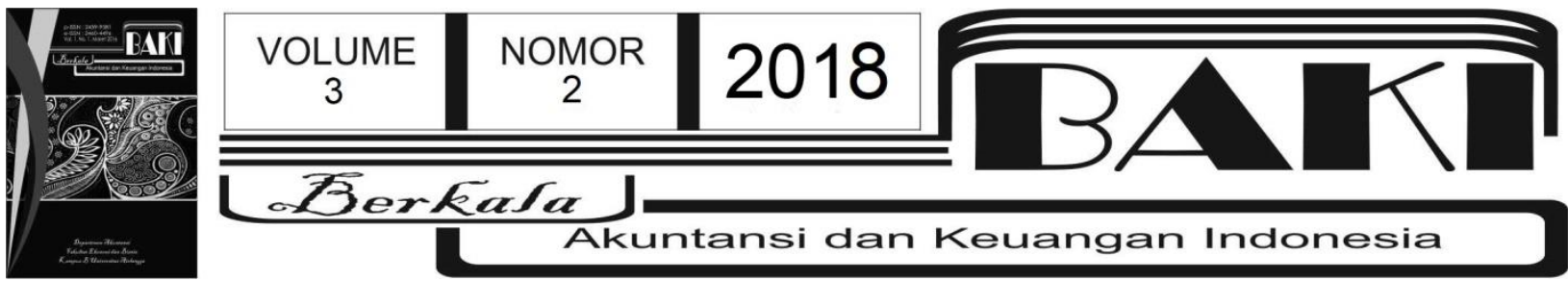

\title{
Mitigasi Manipulasi Laba Aktivitas Rill dengan Keefektifan Internal Governance Studi pada Perusahaan Publik di Indonesia
}

\author{
Carolyn Lukita Sembiring ${ }^{1,2}$ \\ Joicenda Nahumury ${ }^{1,3}$
}

${ }^{1}$ STIE Perbanas Surabaya

2carolyn.lukita@perbanas.ac.id

3joicendra@perbanas.ac.id

INFO ARTIKEL

\section{Histori Artikel:}

Tanggal Masuk 15 Agustus 2018

Tanggal Diterima 30 September 2018

Tersedia Online 30 September 2018

Kata Kunci:

internal governanace;

manipulasi laba rill; abnormal

cfo; abnormal production;

abnormal discretioner
A B STRAK

Penelitian ini bertujuan untuk menguji efektivitas internal governanace untuk memitigasi manipulasi laba aktivitas rill. Manipulasi laba aktivitas rill sebagai variabel dependen diukur dalam tiga proxy, yakni manipulasi aktivitas penjualan (Abnormal CFO), manipulasi biaya produksi (Abnormal Production), dan manipulasi biaya diskresioner (Abnormal Discreationer) berdasarkan Roychowdhury, (2006). Sedangkan variabel independen adalah internal governance, yang tergolong masih sedikit diteliti namun dibeberapa penelitian telah terbukti dapat menurunkan manajemen laba rill. Penelitian ini mengukur internal governance berdasarkan Chen et al., (2016). Penelitian ini juga menguji variabel-variabel lainnya sebagai variabel pemoderasi, yakni kontrol dari dewan komisaris independen dan kepemilikan institusional yang diduga dapat memperkuat efektivitas internal governance dalam memitigasi manipulasi laba. Teknik analisis data yang digunakan adalah regresi linear berganda. Penelitian ini berhasil memberikan bukti bahwa internal governance mampu memitigasi tindakan manipulasi laba yang dilakukan manjer. Selain itu penelitian ini juga memberikan dukungan bahwa kepemilikan institusional dan dewan komisaris independen dapat memoderasi pengaruh antara internal governance dengan manajemen laba rill. Hasil penelitian ini dapat menambah referensi tentang mitigasi manajemen laba rill dan juga sebagai salah satu pertimbangan keputusan investasi jangka panjang di pasar modal bagi investor. 


\section{Pendahuluan}

Fenomena yang terjadi menunjukkan bahwa di antara berbagai topik penelitian dalam bidang akuntansi dan keuangan, manipulasi laba, menjadi salah satu topik yang paling provokatif dan paling memotivasi banyak peneliti untuk melakukan penelitian terkait laba. Hal ini disebabkan karena manupulasi laba merupakan topik yang secara eksplisit melibatkan potensi kesalahan, kerugian, konflik yang dapat merugikan berbagai pihak seperti, shareholders, debitur, karyawan, pemerintah, dan masyarakat secara umum. Kerugian tersebut terjadi karena stakeholders melakukan pengambilan keputusan atas pertimbangan laba yang menyesatkan (Adiasih dan Indra, 2011).

Evaluasi kinerja dan pemberian insentif (bonus) berbasis laba yang dihasilkan, telah banyak dikritik karena dapat menciptakan motivasi bagi CEO untuk terlibat dalam perilaku opportunistic seperti manipulasi laba. Penilaian kinerja berbasis laba telah menimbulkan permasalahan dalam lingkup global seperti, prilaku CEO perusahaan Enron, Worldcom, Xerox, Merck, Tyco, dan Global Crossing berusaha mendapatkan keuntungan paling besar dengan memanipulasi laba. Para CEO dan professional berbagai perusahaan ini bertindak demi kepentingan diri mereka masing-masing dengan mengorbankan kepentingan pihak lain harus menderita kerugian sangat besar akibat pengumuman bangkrutnya Enron yang selama tahuntahun terakhirnya masih mengumumkan laba yang tinggi, yang sebenarnya adalah hasil manipulasi laba, sehingga shareholder harus merelakan harga sahamnya menurun tajam bahkan gagal bayar secara total.

Di Indonesia juga terdapat kasus serupa yakni, skandal Lippo Bank dan PT Qsar pada tahun 2002. Eksekutif dijanjikan hak untuk membeli saham dari perusahaan yang mereka kelola dengan harga saham jauh di bawah harga normal. Hal tersebut membuat CEO termotivasi melakukan tindakan opportunistic melalui manipulasi laba akibat dukungan sistem kompensasi yang berlebihan. Skandal pelaporan keuangan ini mengakibatkan masyarakat memperhatikan peran eksekutif perusahaan (CEO) dalam pengelolaan dan pertanggungjawaban pelaporan keuangan kepada pemangku kepentingan.

Penelitian ini penting untuk dilaksanakan karena bertujuan menemukan metode untuk menurunkan tindakan manipulasi laba aktivitas rill yang dilakukan CEO pada perusahaanperusahaan publik yang terdaftar di Bursa Efek Indonesia, yakni melalui keefektifan internal governance. Penelitian ini menduga bahwa internal governanace mampu menurunkan tingkat manajemen laba rill. Keberadaan metode baru tersebut diharapkan dapat menghindarkan stakeholder dari kerugian akibat pengambilan keputuasan atas pertimbangan laba yang "menyesatkan". 
Internal governance (tata kelola internal) mengacu pada pihak para eksekutif yang posisinya berada di bawah posisi CEO yang disebut dengan Key Subordinate Executive (KSE). Para Key Subordinate Executive (KSE) memberikan checks and balances dalam organisasi serta dapat mempengaruhi keputusan yang diambil oleh CEO. Fokus penelitian ini pada anggota eksekutif utama di bawah CEO (Key Subordinate Executive) atau secara spesifik, empat eksekutif bagian atas dengan kompensasi tertinggi selain CEO seperti yang ditunjukan pada (Gambar 1.1).

\section{Gambar 1.1}

\section{Struktur Organisasi Perusahaan}

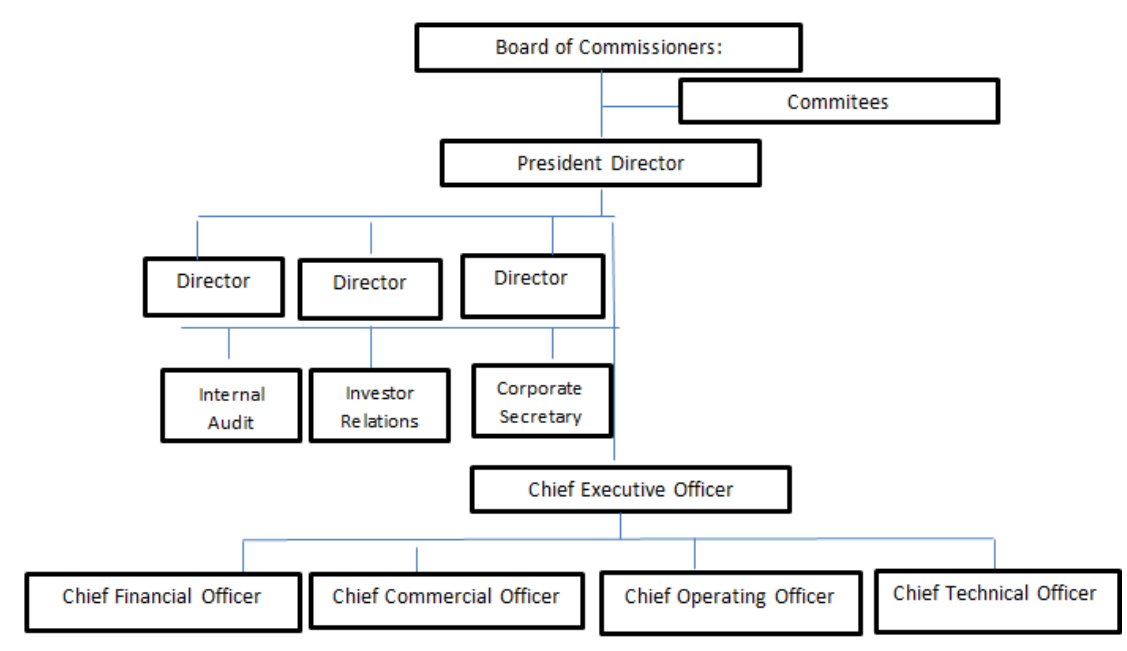

Topik penelitian terkait dengan motivasi, cara dan dampak perilaku oportunistic CEO untuk melakukan manipulasi laba telah semakin berkembang (Amstrong, 2013). Sebagian besar penelitian terdahulu, seperti penelitian Adiasih (2011) yang meneliti tindakan manajemen laba dan prilaku CEO secara individu, namun pada kenyataanya CEO bukanlah satu-satunya pihak yang terlibat dalam proses manipulasi laba. CEO bisa saja menjadi penggerak atau decision makers, namun pelaksana tindakan tersebut justru lebih dipengaruhi oleh eksekutif utama di bawah CEO yang disebut juga dengan Key Subordinate Executive.

Penelitian ini menduga bahwa Key Subordinate Executive adalah kelompok karyawan yang memiliki kemungkinan paling tinggi dan memiliki kemampuan untuk mempengaruhi CEO dalam pengambilan keputusan perusahaan termasuk keputusan manipulasi laba. Seperti yang dikemukakan di Acharya, Myers, dan Rajan (2011), bahwa eksekutif utama di bawah CEO (Key Subordinate Executive) memiliki dorongan kuat untuk tidak mengambil tindakan yang meningkatkan kinerja jangka pendek dengan mengorbankan nilai perusahaan jangka panjang. Upaya meningkatkan kinerja jangka pendek dengan mengorbankan nilai perusahaan jangka panjang merupakan trade-off antara nilai perusahaan saat ini dengan nilai perusahaan masa depan yang sangat menonjol dalam hal keputusan tindakan manajemen laba rill. Tindakan manajemen laba rill seperti produksi berlebih dan pemotongan biaya riset dan pengembangan 
(R\&D) dapat mengurangi potensi nilai jangka panjang perusahaan (Bhojraj, Hribar, Picconi, dan McInnis 2009; Cohen dan Zarowin 2010).

Cremers dan Grinstein (2011) yang menyatakan bahwa 68,6\% dari CEO yang menjabat adalah CEO yang dipromosikan dari dalam perusahaan itu sendiri dimana, dalam $68,6 \%$ kasus turnover, satu dari key subordinate CEO menjadi penerus CEO sebelumnya. Maka dapat dikatakan bahwa Key Subordinate Executive adalah CEO potensial dimasa depan. Maka key subordinate executives concern terhadap aliran kas yang mengindikasikan peluang perusahaan kedepannya. Berdasarkan penjelasan tersebut diduga bahwa key subordinate executives lebih peduli terhadap investasi jangka panjang.

Penelitian Adiasih dan Indra (2011) menunjukkan bahwa di Indonesia terdapat peristiwa CEO yang baru terpilih akan memilimalkan laba yang dilaporkan, sedangkan pada akhir periode pergantian CEO akan menunjukkan manajemen laba yang tinggi untuk mencapai pelaporan target laba. Penelitian tersebut mengindikasikan bahwa CEO yang berada pada akhir masa kepemimpinanya akan berfokus pada laba jangka pendek, dan mengabaikan laba jangka panjang. Penelitian Chen et al., (2016) menunjukkan bahwa internal governance dapat menurunkan manajemen laba rill. Internal governance dapat menurunkan tingginya motivasi manajemen laba oleh CEO pada akhir periode kepemimpinannya. Penelitian ini ingin menguji kembali penelitian Chen et al., (2016) yang menguji hubungan internal governance terhadap manipulasi laba rill, namun kebaharuan dalam penelitian ini adalah dengan menambahkan variabel pemoderasi yaitu, kepemilikan internal dan dewan komisaris independen yang diduga dapat memperkuat internal governanace dan semakin menurunkan tindakan oportinistic CEO untuk melakukan manipulasi rill. Berdasarkan penjelasan di atas maka, dapat disimpulkan bahwa penelitian ini ingin menguji apakah internal governance yang efektif dapat menurunkan atau memitigasi tindakan manajemen laba rill yang dilakukan oleh CEO.

\section{Tinjauan Pustaka}

\subsection{Internal Governance dan Manajemen Laba Rill}

Internal governance pada penelitian ini diukur menggunakan opportunity key subordinate executives, mengacu pada pihak para eksekutif yang posisinya berada di bawah posisi CEO. Key subordinate executives memiliki umur yang cenderung lebih muda dari pada CEO pada perusahaan (Chen et al., 2016). Oleh karena itu Key subordinate executives memiliki kompensasi masa depan yang lebih besar dibandingkan CEO itu sendiri. Penelitian Cremers dan Grinstein (2011) menyatakan bahwa 68,6\% dari CEO yang menjabat saat ini merupakan CEO yang dipromosikan dari dalam perusahaan itu sendiri, atau karyawan yang sebelumnya pernah menjabat sebagai Key subordinate executives. Key subordinate executives 
lebih besar menanggung kerugian masa depan dari kinerja perusahaan yang buruk saat ini dibandingkan dengan CEO, dengan demikian Efek ini dapat memotivasi para key subordinate eksekutif untuk lebih berorientasi pada jangka panjang dan untuk melakukan pemantauan terhadap CEO yang justru memiliki kecenderungan orientasi keuntungan jangka pendek.

Manipulasi laba rill merupakan perekayasaan laba oleh manajemen yang bertujuan untuk meningkatkan laba saat ini, namun dapat merugikan kinerja jangka panjang perusahaan. Manipulasi laba rill merupakan manipulasi laba dengan melakukan aktivitas-aktifitas rill. Manipulasi laba rill dapat dilakukan dengan tiga cara yakni; (1) abnormal biaya produksi (2) abnormal cash flow dan (3) abnormal biaya diskresioner. (1) Manajemen laba melalui abnormal biaya produksi dilakukan dengan peningkatan jumlah produksi yang mengakibatkan biaya overhead tetap dibagi dengan jumlah unit barang yang besar akan menghasilkan rata-rata biaya perunit dengan harga pokok penjualan menurun. Tindakan abnormal biaya produksi dapat meningkatkan profit margin pada periode berjalan, namun tindakan over produksi yang tidak dibarengi dengan peningkatan penjualan dapat merugikan perusahaan dimasa depan, karena peningkatan baiaya gudang, kemungkinan persediaan usang, dan penurunan tingkat perawatan mesin. (2) Abnormal arus kas operasi berkaitan dengan manajemen penjualan dan upaya yang dilakukan untuk meningkatkan penjualan sesuai target, seperti melakukan penawaran harga diskon berlebihan dan melakukan persyaratan kredit yang lunak. Hal ini dilakukan agar mencapai target penjualan jangka pendek, namun merugikan peluang jangka panjang karena terdapat kemungkinan piutang tak tertagih, dan brand image yang buruk bagi konsumen. (3) Abnormal biaya diskresioner merupakan manipulasi laba terkait biaya-biaya seperti, biaya iklan, biaya riset dan pengembangan, biaya penjualan, serta biaya administrasi dan umum. Dalam upaya meningkatkan laba jangka pendek perusahaan dapat menurunkan biaya-biaya tersebut. Namun pengurangan biaya seperti biaya R\&D dan biaya iklan dapat menurunkan peluang jangka panjang perusahaan untuk bersaing secara kompetitif di masa yang akan datang.

Key subordinate eksekutif memiliki kekuatan memengaruhi keputusan CEO untuk tidak berorientasi jangka pendek dengan melakuakan manipulasi laba. Keberhasilan CEO saat ini bergantung pada arus kas pada periode saat ini, yang dipengaruhi oleh kinerja key subordinate executive. Jika CEO tidak mempertimbangkan kepentingan Key subordinate executives, maka key subordinate executive dapat kurang termotivasi dalam bekerja dan kurang tekun, sehingga mengurangi arus kas saat ini dan kesejahteraan CEO saat ini (Allen and Gale 2000; Acharya dkk 2011). Mengantisipasi hal tersebut, maka CEO perlu mempertimbangkan saran dan kepentingan bawahan, agar Key subordinate executives tidak kehilangan motivasi untuk bekerja lebih keras (Landier, Sraer, dan Thesmar, 2009).

Apabila CEO memilih untuk melakukan tindakan manipulasi aktivitas rill yang menurunkan nilai perusahaan jangka panjang, maka Key subordinate executives akan memilih 
tingkat usaha yang lebih rendah. Mengantisipasi hal ini, CEO akan cenderung tidak terlibat dalam manipulasi aktivitas rill. Apabila CEO tidak terlibat dalam manajemen pendapatan riil, maka akan selaras dengan kepentingan Key subordinate executives. Atas dasar persamaan kepentingan CEO dan Key subordinate executives akan bekerja lebih keras untuk memperbaiki kinerja perusahaan saat ini maupun di masa depan. Sebagai tambahan, CEO perlu kooperatif dengan para Key subordinate executives untuk terlibat dalam manajemen pendapatan riil karena eksekutif bawahan biasanya lebih banyak mendapat informasi daripada CEO di wilayah fungsional mereka sendiri. Sehingga, CEO harus mempertimbangkan preferensi Key subordinate executives tersebut. Secara keseluruhan, efektivitas pengaruh key subordinat eksekutif dalam mengendalikan perilaku CEO bergantung pada cara pandang dan kemampuan mereka untuk memengaruhi keputusan CEO. Semakin berpengalaman dan semakin luas pengetahuan key subordinat eksekutif maka semakin kuat pengaruhnya dalam pengambilan keputusan, semakin efektif pula tata kelola internal pada sebuah perusahaan, dan semakin kecil kemungkinan perusahaan akan terlibat dalam manajemen pendapatan riil. Berdasarkan uraian tersebut maka disusun hipotesis pertama adalah sebagai berikut:

H1a: Internal governance berpengaruh negatif terhadap manipulasi laba yang dilakukan melalui abnormal biaya produksi

H1b: Internal governance berpengaruh negatif terhadap manipulasi laba yang dilakukan melalui abnormal biaya diskrisioner

H1c: Internal governance berpengaruh negatif terhadap manipulasi laba yang dilakukan melalui abnormal arus kas oprasi

\subsection{Internal Governance, Komisaris Independen, Kepemilikan Institusional dan Manajemen Laba Rill}

Investor institusional adalah pemantau yang lebih baik dibandingkan pemegang saham lainnya (misalnya Bushee 1998; Chen at.al., 2007). Investor institusioanal dapat menjadi suatu media control dari tindakan manajemen, karena memiliki kekuatan voting dan hak suara. Serta kecenderungan bahwa investor institusional merupakan investor dikelola oleh manajer investasi yang ahli dibidangnya. Berdasarkan penjelasan tersebut diprediksi bahwa efektivitas tata kelola internal meningkat seiring dengan peningkatan kepemilikan institusional. Kemampuan Key subordinate executives untuk memengaruhi keputusan CEO kemungkinan besar dipengaruhi oleh seberapa kuat CEO mereka. Menurut Adams et. al. (2005), CEO yang baik adalah mereka yang secara konsisten dapat memengaruhi keputusan penting di perusahaan mereka, terlepas dari potensi oposisi dari eksekutif lain. Di perusahaan-perusahaan di mana CEO berkuasa, otoritas pembuat keputusan biasanya dipusatkan di tangan CEO karena itu, para CEO ini dapat mendorong keputusan mereka bahkan jika keputusan tersebut dapat dianggap suboptimal. 
Konsisten dengan logika pemikiran tersebut, Feng et al. (2011) menemukan bahwa CFO (chief financial officer) kemungkinan besar bergantung pada tekanan CEO yang kuat untuk memanipulasi laporan keuangan. Oleh karena itu, penelitian ini mengharapkan Key subordinate executives memiliki kemampuan yang lebih rendah untuk memengaruhi keputusan CEO saat CEO memegang kekuatan dan wewenang besar di dalam perusahaan. Sebaliknya, diharapkan tata kelola internal menjadi lebih efektif dalam membatasi tingkat pengelolaan laba riil ketika CEO kurang kuat dan oleh karena itu, hipotesis yang menerangkan kepemilikan Institusional sebagai pemoderasi dituliskan sebagai berikut:

H2a: Efektivitas internal governance dalam mengurangi tingkat manipulasi laba riil yang dilakukan melalui abnormal biaya produksi akan lebih kuat untuk perusahaan yang memiliki tingkat pengawasan dari komisaris kepemilikan institusional yang lebih tinggi

H2b: Efektivitas internal governance dalam mengurangi tingkat manipulasi laba riil yang dilakukan melalui abnormal biaya diskrisioner akan lebih kuat untuk perusahaan yang memiliki tingkat pengawasan dari kepemilikan institusional yang lebih tinggi

H2c: Efektivitas internal governance dalam mengurangi tingkat manipulasi laba riil yang dilakukan melalui abnormal arus kas operasi akan lebih kuat untuk perusahaan yang memiliki tingkat pengawasan dari kepemilikan institusional yang lebih tinggi

\subsection{Internal Governance, Komisaris Independen, dan Manajemen Laba Rill}

Penelitian ini memprediksi bahwa keinginan CEO untuk melakukan manipulasi laba menjadi kurang kuat saat ada mekanisme tata kelola yang baik. Penelitian terdahulu menunjukkan bahwa efektivitas pemantauan dari dewan komisaris akan meningkat dengan adanya independensi dewan yang tinggi pada perusahaan tersebut (Weisbach 1988). Berdasarkan penjelasan tersebut diprediksi bahwa efektivitas tata kelola internal meningkat seiring dengan peningkatan independensi dewan (dewan komisaris independen). Efendi (2016), menjelaskan bahwa danya pengaruh komisaris independen sebagai pemoderasi terhadap manajemen laba rill. Berdasarkan penjelasan tersebut, maka hipotesis yang menerangkan dewan komisaris independen sebagai pemoderasi, dituliskan sebagai berikut:

H3a: Efektivitas internal governance dalam mengurangi tingkat manipulasi laba riil yang dilakukan melalui abnormal biaya produksi akan lebih kuat untuk perusahaan yang memiliki tingkat pengawasan dari komisaris Independen yang lebih tinggi.

H3b: Efektivitas internal governance dalam mengurangi tingkat manipulasi laba riil yang dilakukan melalui abnormal biaya diskrisioner akan lebih kuat untuk perusahaan yang memiliki tingkat pengawasan dari komisaris Independen yang lebih tinggi. 
H3c: Efektivitas internal governance dalam mengurangi tingkat manipulasi laba riil yang dilakukan melalui abnormal arus kas oprasi akan lebih kuat untuk perusahaan yang memiliki tingkat pengawasan dari komisaris Independen yang lebih tinggi.

\section{Metodologi Penelitian}

\subsection{Definisi Oprasional Variabel}

\subsubsection{Manajemen Laba Rill Sebagai Variabel Dependen}

Variabel dependen yang digunakan dalam penelitian ini adalah manipulasi laba rill. Model untuk menghitung biaya produksi abnormal menggunakan model regresi cross-sectional yang digunakan oleh Roychowdhury (2006).

$$
\frac{P R O D \text { it }}{\text { Assets } i t-1}=K 0+k 1 \frac{1}{\text { Assets } i t-1}+k 2 \frac{\text { SALES } i t}{\text { Assets } i t-1}+k 3 \frac{\Delta S A L E S \text { it }}{\text { Assets } i t-1}+k 4 \frac{\Delta S A L E S \text { it }-1}{\text { Assets } i t-1} €
$$

\section{Keterangan:}

\begin{tabular}{|c|c|c|}
\hline $\begin{array}{l}P_{R O D} \\
\text { Assets }_{\text {it-1 }}\end{array}$ & $\begin{array}{l}= \\
=\end{array}$ & $\begin{array}{l}\text { Biaya produksi perusahaan I pada tahun } t \\
\text { Nilai total asset perusahaan I, } 1 \text { tahun sebelum tahun } t\end{array}$ \\
\hline $\begin{array}{l}\text { ALES }_{t} \\
\text { SALES }_{\text {it }} \\
\text { SALES }_{\text {it-1 }} \\
\mathrm{E}_{\text {it }}\end{array}$ & $\begin{array}{l}= \\
= \\
=\end{array}$ & $\begin{array}{l}\text { Nilai perubahan penjualan pada tahun } \mathrm{t} \text { terhadap } \mathrm{t}-1 \\
\text { Penjualan perusahaan I pada tahun } \mathrm{t} \\
\text { Nilai perubahan penjualan pada tahun } \mathrm{t}-1 \text { terhadap } \mathrm{t}-2 \\
\text { Error term }\end{array}$ \\
\hline
\end{tabular}

Model untuk menghitung biaya diskresioner abnormal menggunakan model regresi crosssectional yang digunakan oleh Roychowdhury (2006). untuk mengestimasi koefesien dari persamaan berikut:

$$
\frac{A B D I S X}{\text { Assets } i t-1}=k 1 \frac{1}{\text { Assets } i t-1}+k 2 \frac{\text { SALES } \text { it }}{\text { Assets } i t-1}+e
$$

\section{Keterangan:}

$\begin{array}{lll}\text { ABDISEX } & = & \text { Arus kas kegiatan oprasi perusahaan I pada tahun } \mathrm{t} \\ \text { Assets }_{\mathrm{it}-1} & = & \text { Nilai total asset perusahaan } \mathrm{i}, 1 \text { tahun sebelum tahun } \mathrm{t} \\ \text { SALES }_{\text {it }} & = & \text { Penjualan perusahaan I pada tahun } \mathrm{t} \\ \mathrm{e}_{\mathrm{it}} & = & \text { Error term }\end{array}$

Model untuk menghitung abnormal cash flow operation (Abnormal CFO) menggunakan model regresi cross-sectional yang digunakan oleh Roychowdhury (2006). untuk mengestimasi koefesien dari persamaan berikut: 
$\frac{C F O \text { it }}{\text { Assets } i t-1}=K 0+k 1 \frac{1}{\text { Assets it }-1}+k 2 \frac{\text { SALES } \text { it }}{\text { Assets } i t-1}+k 3 \frac{\Delta S A L E S \text { it }}{\text { Assets } i t-1}+e$

\section{Keterangan:}

$\begin{array}{lll}\text { PROD }_{\text {it }} & = & \text { Biaya produksi perusahaan I pada tahun } \mathrm{t} \\ \text { Assets }_{\text {it-1 }} & = & \text { Nilai total asset perusahaan I, } 1 \text { tahun sebelum tahun } \mathrm{t} \\ \mathrm{SALES}_{\text {it }} & = & \text { Nilai perubahan penjualan pada tahun } \mathrm{t} \text { terhadap } \mathrm{t}-1 \\ \text { SALES }_{\text {it }} & = & \text { Penjualan perusahaan I pada tahun } \mathrm{t} \\ \Delta \text { SALES }_{\text {it-1 }} & = & \text { Nilai perubahan penjualan pada tahun } \mathrm{t}-1 \text { terhadap } \mathrm{t}-2 \\ \mathrm{e}_{\mathrm{it}} & = & \text { Error term }\end{array}$

\subsubsection{Internal Governance Sebagai Variabel Independen}

Variabel dependen yang digunakan dalam pelitian ini adalah internal governance yang diukur dengan opportunity of key subordinate executives, mengacu pada pihak para eksekutif yang posisinya berada di bawah posisi CEO. Untuk mengukur opportunity key subordinate executives menggunakan rata selisih antara usia para key subordinate executives dengan jumlah tahun sampai usia pensiun (diasumsikan 65tahun) (Chen et al., 2016).

\begin{tabular}{|c|c|}
\hline Opportunity of key $=$ & $\sum$ 65th- Usia Saat ini \\
subordinate executives
\end{tabular}

\subsubsection{Kepemilikan Institusional sebagai Variabel Pemoderasi}

Variabel kepemilikan institusional menggunakan proporsi kepemilikan saham institusional, yaitu rasio antara kepemilikan saham institusional terhadap total saham beredar (Young et al., 2011).

\begin{tabular}{|cc|}
\hline $\begin{array}{c}\text { Kepemilikan } \\
\text { Institusional }\end{array}$ & $\frac{\text { Kepemilikan Saham Institusional }}{\text { Total Saham Beredar }}$ \\
\hline
\end{tabular}

\subsubsection{Dewan Komisaris Independen sebagai Variabel Pemoderasi}

Board Independence atau dewan komisaris yang independen diukur dengan PINED (Proportion Independent Director) pada dewan perusahaan. Dewan komisaris dikatakan independent jika mereka tidak memiliki hubungan dengan perusahaan dan tidak memiliki transaksi dengan pihak-pihak terkait dengan perusahaan (Jaggi et al., 2009).

\begin{tabular}{|c|c|}
\hline Dewan Komisaris = & Komisaris Independen \\
\hline Independen & Jumlah Dewan Komisaris \\
\hline
\end{tabular}




\subsection{Model yang Digunakan}

Model penelitian yang digunakan dalam penelitian ini adalah sebagai berikut:

Gambar 2.1

Model Penelitian

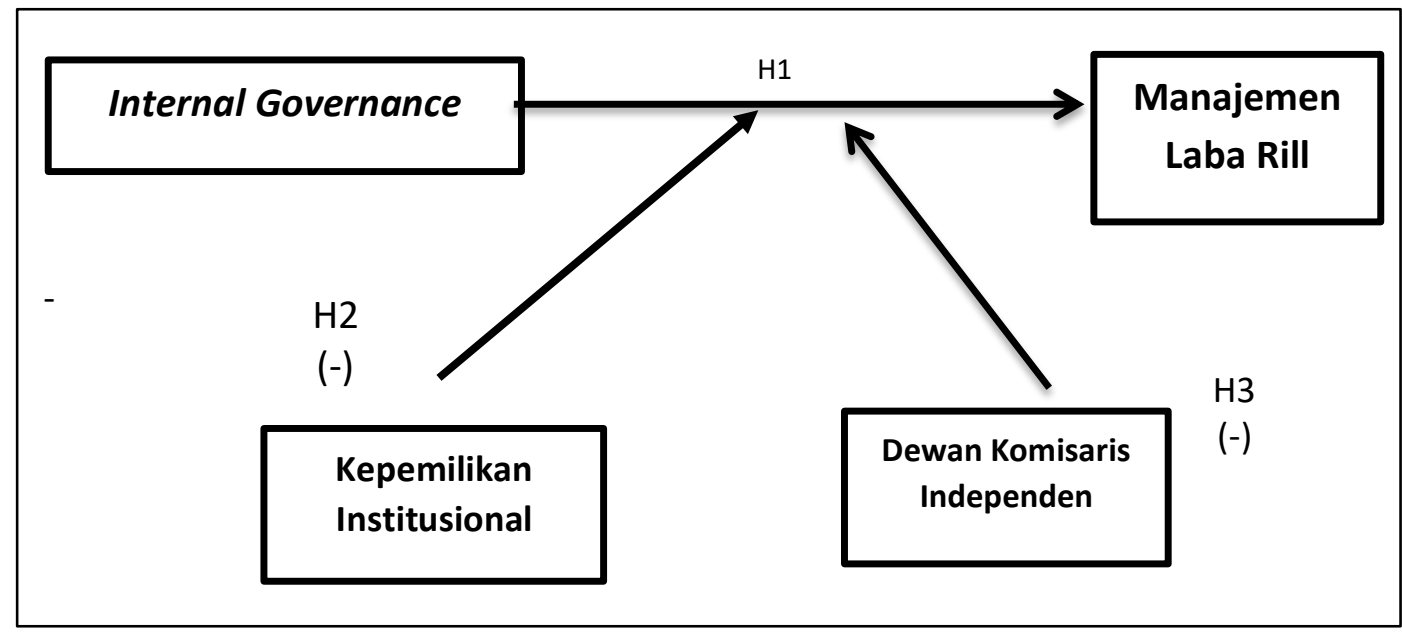

\subsection{Teknik Pengumpulan dan Analisis Data}

\subsubsection{Teknik Pengumpulan Sampel}

Teknik pengumpulan sampel pada penelitian ini menggunakan purposive sampling artinya pengembilan sampel dengan menggunakan kriteria-kriteria tertentu yaitu sebagai berikut:

1. Perusahaan yang terdaftar di BEI

2. Konsisten terdaftar dan melaporkan laporan keuangan

3. Melaporkan laporkan keuangan dalam satuan rupiah

4. Mengungkapkan semua informasi yang dibutuhkan dalam pengukuran variabel penelitian

\subsubsection{Metode Pengumpulan Data}

Sumber data yang digunakan dalam penelitian ini adalah sumber data sekunder yaitu sumber data yang diperoleh dari laporan keuangan perusahaan yang terdaftar di BEI pada tahun 2014-2016. Teknik pengumpulan data yang digunakan dalam penelitian ini adalah teknik dokumentasi yaitu dengan mendokumentasikan data-data laporan keuangan dan laporan tahunan yang telah dikumpulkan. 


\subsubsection{Teknik Analisis Data}

Teknik analisis yang digunakan dalam penelitian ini menggunakan analisis regresi linear berganda. Persamaan regresi dapat dinyatakan sebagai berikut (Ghozali, 2005).

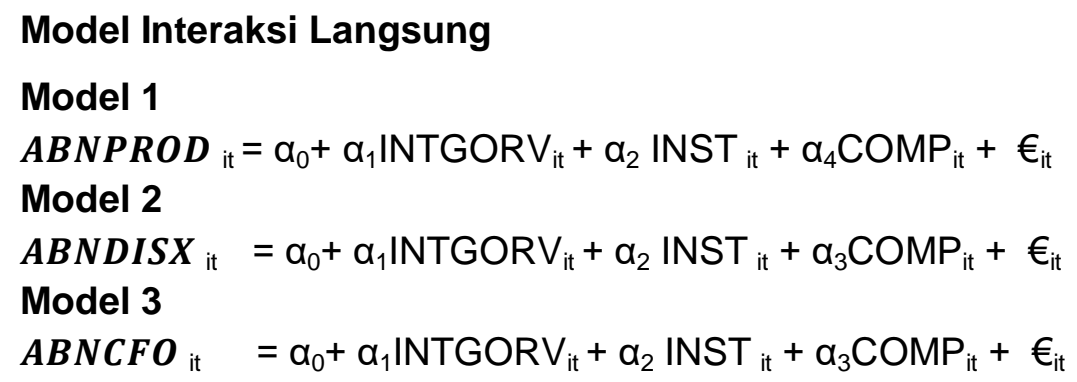

\section{Model dengan Variabel Kepemilikan Institusional Sebagai Pemoderasi Model 4}

ABNPROD ${ }_{\text {it }}=\alpha_{0}+\alpha_{1}$ INTGORV $_{\text {it }}+\alpha_{2}$ INST $_{\text {it }}+\alpha_{3}$ COMP $_{\text {it }}+\alpha_{4}$ INST $^{*}$ INTGORV $+\epsilon_{\text {it }}$ Model 5

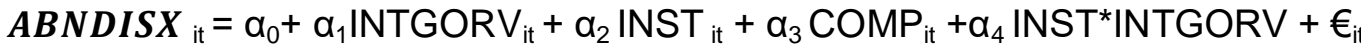
Model 6

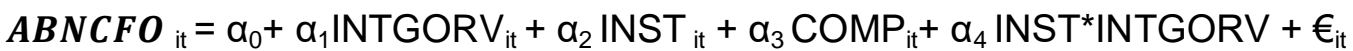

Model dengan Variabel Dewan Komisaris Independen Sebagai Pemoderasi Model 7

ABNPROD ${ }_{\text {it }}=\alpha_{0}+\alpha_{1}$ INTGORV $_{\text {it }}+\alpha_{2}$ INST $_{\text {it }}+\alpha_{3}$ COMP $_{\text {it }}+\alpha_{4}$ COMP $_{\text {it }}{ }^{*}$ INTGORV $+\epsilon_{\text {it }}$ Model 8

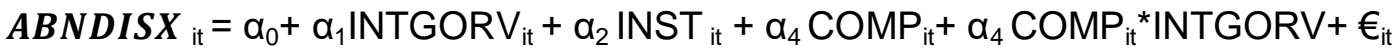
Model 9

$\boldsymbol{A B N C F O}$ it $=\alpha_{0}+\alpha_{1}$ INTGORV $_{\text {it }}+\alpha_{2}$ INST $_{\text {it }}+\alpha_{4}$ COMP $_{\text {it }}+\alpha_{4}$ COMP $_{\text {it }}{ }^{*}$ INTGORV $+e$

\subsubsection{Uji Hipotesis}

Uji hipotesis dilakukan dengan menggunakan uji regresi linear berganda untuk menguji pengaruh variabel independen dan pemoderasi terhadap variabel dependen, untuk memperoleh hasil dari diterima atau ditolaknya hipotesis penelitian. Uji hipotesis terdiri dari tiga bagian, yaitu mengenai uji $F$, uji koefesien determinasi $\left(R^{2}\right)$, dan uji t.

\section{Analisis dan Pembahasan}

\subsection{Pengumpulan Data}

Populasi dalam penelitian ini adalah seluruh perusahaan publik yang terdaftar di BEI, dengan periode penelitian selama 3 tahun yakni tahun 2014-2016. 
Tabel 4.1. Proses Pemilihan Sampel

\begin{tabular}{|l|l|c|}
\hline No & \multicolumn{1}{|c|}{ Keterangan } & Jumlah \\
\hline 1 & Seluruh Perusahaan yang terdaftar di BEI & 566 \\
\hline 2 & $\begin{array}{l}\text { Perusahaan pertambangan yang tidak konsisten } \\
\text { menerbitkan laporan tahunan dan laporan keuangan } \\
\text { selama periode penelitian }\end{array}$ & $(110)$ \\
\hline 3. & $\begin{array}{l}\text { Perusahaan yang tidak memiliki data lengkap terkait } \\
\text { variabel penelitian yang dibutuhkan }\end{array}$ & $\mathbf{3 6 6}$ \\
\hline & Jumlah Sampel yang digunakan & $\mathbf{3}$ \\
\hline & Periode penelitian (tahun) & $\mathbf{1 0 9 8}$ \\
\hline & Total perusahaan selama 5 tahun & $\mathbf{( 1 1 4 )}$ \\
\hline & Jumlah observasi yang outlier & $\mathbf{9 8 4}$ \\
\hline & Jumlah akhir observasi penelitian & \\
\hline
\end{tabular}

Sumber: data diolah

\subsection{Statsitik Deskriptif}

Deskriptif statistik dialakukan untuk memberikan gambaran terhadap data mengenai nilai ninimum, maksimum, rata-rata dan standar deviasi.

Tabel 4.2. Deskriptif Statistik

\begin{tabular}{|l|c|c|c|c|}
\multicolumn{1}{|c|}{ Variabel } & Minimum & Maximum & Mean & Std. Deviation \\
\hline $\begin{array}{l}\text { Internal Governance } \\
\text { Key Subordinate Executive }\end{array}$ & $-6,67$ & 37.0 & 14,23 & 7,30 \\
\hline Abnormal Produksi & $-2,12$ & 3,47 & 0,144 & 0,603 \\
\hline Abnormal Diskresioner & $-1,67$ & 9,37 & 0,11 & 0,623 \\
\hline Abnormal CFO & $-0,51$ & 1,17 & $-0,196$ & 0,132 \\
\hline Kepemilikan Institusional & 0,00 & 0,99 & 0,5689 & 0,27026 \\
\hline Dewan Komisaris Independen & 0,25 & 1,00 & 0,4291 & 0,12869 \\
\hline
\end{tabular}

Sumber: SPSS, Data diolah.

Tabel 4.2 menunjukkan hasil statistik deskriptif untuk setiap variabel. Internal governance menunjukkan nilai minimum yang negatif yakni -6,67 menunjukkan adanya key subordinate executive yang tetap dipkerjakan meskipun telah melewati batas usia pensiun 65 tahun. Nilai maksimum 37 tahun menunjukkan bahwa terdapat key subordinate executive yang masih berusia muda, yakni 37 tahun sebelum masa pensiunnya. Sedangkan mean dengan nilai 14,23 tahun menunjukkan rata-rata perusahaan memperkerjakan key subordinate executive yang berusia 51 tahun.

Variabel dependen manajemen laba rill dalam penelitian ini diukur dalam tiga pengukuran yaitu abnormal produksi, abnormal diskresioner dan abnormal CFO. Berdasarkan statistik deskriptif abnormal produksi menunjukkan nilai minimum $-2,12$ nilai maksimum 3,47 dan mean 0,144. Perusahaan dikatakan memiliki kecendrungan melakukan abnormal produksi jika menujukan nilai abnormal produksi di atas 1 , hal ini menunjukkan bahwa pada perusahaan publik di Indonesia memiliki kecenderungan abnormal produksi sebesar 0,144 namun masih berada di bawah angka 1 sehingga menunjukkan abnormal produksi yang rendah. Abnormal 
diskresioner menunjukkan nilai minimum sebesar -1,67 nilai maksimum 9,37 dan rata-rata 0,11. Perusahaan dikatakan menunjukkan kecenderungan melakukan abnormal produksi jika di atas nilai 1. Rata-rata perusahaan yang bernilai 0,11 menunjukkan bahwa perusahaan publik di Indonesia cenderung kecil melakukan abnormal diskresioner. Abnormal CFO menunjukkan nilai minimum $-0,51$ nilai maksimum 1,17 dan rata-rata $-0,196$. Hal ini menujukkan bahwa terdapat nilai kecendrungan yang kecil dalam abnormal CFO.

Kepemilikan institusional menunjukkan nilai minimum 0,00 yang berarti terdapat perusahaan yang sahamnya samasekali tidak dimiliki oleh investor institusional. Nilai maksimum menunjukkan angka 0,99 berarti terdapat perusahaan yang investor-nya mayoritas terdiri dari investor-investor institusional. Sedangkan nilai rata-rata yakni 0,56 hal ini menunjukkan bahwa pada perusahaan publik di Indonesia yang terdaftar di BEI lebih dari 50\% dimiliki oleh investor institusional.

Statistik deskriptif untuk dewan komisaris independen menunjukkan nilai minimum yakni 0,25 nilai tersebut menunjukkan terdapat perusahaan yang $25 \%$ dari dewan komisarisnya merupakan pihak luar perusahaan. Nilai maksimum menujukkan angka 1,00 yang berarti bahwa terdapat perusahaan yang seluruh dewan komisarisnya berasal dari pihak luar perusahaan atau independen. Mean menujukkan nilai 0,4291 yang berarti rata-rata perusahaan memiliki 42\% dewan komisaris yang berasal dari luar perusahaan atau independen dari kepentingan perusahaan.

\subsection{Uji Asumsi Klasik}

\subsubsection{Uji Normalitas}

Tabel 4.3. Uji Normalitas (One- Sampel Kolmogorov-Smirnov)

\begin{tabular}{|c|c|c|c|}
\hline \multicolumn{4}{|c|}{ Model Interaksi Langsung } \\
\hline & Model 1 & Model 2 & Model 3 \\
\hline Std. Dev & 0,619 & 1,8484 & 1,50579 \\
\hline Kolmogrov-Smirnv Z & 0,800 & 0,648 & 0,600 \\
\hline Asymo.Sig. (2-tailed) & 0,543 & 0,795 & 0,864 \\
\hline $\mathrm{N}$ & 984 & 984 & 984 \\
\hline \multicolumn{4}{|c|}{ Model Dengan Kepemilikan Institusional Sebagai Pemeoderasi } \\
\hline Std. Dev & 0,6090 & 1,847 & 1,5129 \\
\hline Kolmogrov-Smirnv Z & 0,719 & 0,628 & 0,493 \\
\hline Asymo.Sig. (2-tailed) & 0,680 & 0,826 & 0,968 \\
\hline \multicolumn{4}{|c|}{ Model Dengan Dewan Komisaris Independen Sebagai Variabel Pemoderasi } \\
\hline $\mathrm{N}$ & 984 & 984 & 984 \\
\hline Std. Dev & 1,5765 & 1,934 & 1,519 \\
\hline Kolmogrov-Smirnv Z & 0,676 & 0,56 & 0,482 \\
\hline Asymo.Sig. (2-tailed) & 0,750 & 0,912 & 0,974 \\
\hline $\mathrm{N}$ & 984 & 984 & 984 \\
\hline
\end{tabular}

Sumber: SPSS, data diolah 
Berdasarkan hasil pada tabel di atas pengujian terhadap unstandardized residual menghasilkan significance lebih besar dari 0,05. Sesuai kaidah pengujian maka dapat disimpulkan bahwa data pada keseluruhan model berdistribusi normal.

\subsubsection{Uji Autokorelasi}

Pengujian asumsi klasik autokorelasi dengan pendekatan Durbin Watson (DW). Pedekatan tersebut mensyaratkan bahwa autokorelasi tidak terjadi apabila DW berada antara du dan 4-du. Hasil pengujian autokorelasi dalam penelitian ini ditunjukkan sebagai berikut ini.

Tabel 4.7. Nilai Durbin-Watson (DW) Test: Model Interaksi Langsung

\begin{tabular}{|c|c|c|c|}
\hline & Model 1 & Model 2 & Model 3 \\
\hline Durbin-Watson & 1,813 & 1,865 & 1,697 \\
\hline Du & 1,54 & 1,54 & 1,54 \\
\hline 4-du & 2,46 & 2,46 & 2,46 \\
\hline
\end{tabular}

Tabel 4.8. Nilai Durbin-Watson (DW) Test: Model dengan Variabel Kepemilikan Institusional Sebagai Pemoderasi

\begin{tabular}{|c|c|c|c|}
\hline & Model 1 & Model 2 & Model 3 \\
\hline Durbin-Watson & 1,895 & 1,849 & 2,052 \\
\hline $\mathrm{Du}$ & 1,54 & 1,54 & 1,54 \\
\hline $4-d u$ & 2,46 & 2,46 & 2,46 \\
\hline
\end{tabular}

Tabel 4.9. Nilai Durbin-Watson (DW) Test: Model dengan Variabel Dewan Komisaris Independen Sebagai Pemoderasi

\begin{tabular}{|c|c|c|c|}
\hline & Model 1 & Model 2 & Model 3 \\
\hline Durbin-Watson & 2,010 & 2,355 & 2,133 \\
\hline Du & 1,54 & 1,54 & 1,54 \\
\hline $4-d u$ & 2,46 & 2,46 & 2,46 \\
\hline
\end{tabular}

Tabel 4.7-Tabel 4.9: Sumber: data olahan SPSS

Berdasarkan hasil pengujian autokorelasi menunjukkan bahwa Oleh karena nilai DW 2,133 lebih besar dari batas atas (du) 1,54 dan kurang dari 4 - 1,54 (4 - du) 2,46, maka dapat disimpulkan bahwa tidak ada autokorelasi.

\subsubsection{Uji Heteroskedastisitas}

Pengujian ini dilakukan dengan meregresikan nilai absolut terhadap variabel independen. Hasil perhitungan tidak menemukan adanya variabel independen yang secara signifikan mempengaruhi nilai absolut residual. Hasil pengujian heteroskedastisitas pada penelitian ini ditunjukan pada tabel berikut ini. 
Tabel 4.10. Uji Heteroskedastisitas: Model Interaksi Langsung

\begin{tabular}{|c|c|c|c|}
\hline \multirow[t]{2}{*}{ Variabel } & \multicolumn{3}{|c|}{ Sig } \\
\hline & Model 1 & Model 2 & Model 3 \\
\hline Internal Governance & 0,632 & 0,651 & 0,391 \\
\hline Kepemilikan Institusional & 0,072 & 0,601 & 0,296 \\
\hline Dewan Komisaris Independen & 0,309 & 0,536 & 0,858 \\
\hline
\end{tabular}

Tabel 4.11. Uji Heteroskedastisitas: Model dengan Variabel Kepemilikan Institusional Sebagai Pemoderasi

\begin{tabular}{|c|c|c|c|}
\hline \multirow[t]{2}{*}{ Variabel } & \multicolumn{3}{|c|}{ Sig } \\
\hline & Model 4 & Model 5 & Model 6 \\
\hline Internal Governance & 0,273 & 0,482 & 0,312 \\
\hline Kepemilikan Institusional & 0,595 & 0,862 & 0,928 \\
\hline Dewan Komisaris Independen & 0,378 & 0,356 & 0,952 \\
\hline Inst*IntGov & 0,176 & 0,491 & 0,784 \\
\hline
\end{tabular}

Tabel 4.12. Uji Heteroskedastisitas: Model dengan Variabel Dewan Komisaris Independen Sebagai Pemoderasi

\begin{tabular}{|l|c|c|c|}
\multicolumn{2}{|c}{ Variabel } & Model 7 & Sig \\
Internal Governance & 0,763 & 0,679 & 0,864 \\
\hline Kepemilikan Institusional & 0,256 & 0,244 & 0,717 \\
\hline Dewan Komisaris Independen & 0,139 & 0,685 & 0,450 \\
\hline Comp*IntGov & 0,446 & 0,820 & 0,490 \\
\hline
\end{tabular}

Tabel 4.10-Tabel 4.12: Sumber: hasil olahan data SPSS

Hasil pengujian asumsi klasik yang telah dipaparkan sebelumnya menunjukkan bahwa pada model penelitian ini telah memenuhi asumsi klasik baik untuk uji normalitas, uji motlikolinearitas, uji autokorelasi dan uji heteroskedasitas, sehingga ketiga model dalam penelitian ini menjadi best linear unbiased error (BLUE).

\subsection{Pengujian Hipotesis}

Pengujian hipotesis dilakukan untuk mengetahui pengaruh internal governance sebagai variabel dependen terhadap manajemen laba rill. Selain itu untuk menguji apakah kepemilikan institusional dan dewan komisaris independen dapat memoderasi hubungan tersebut.

\section{Model Interaksi Langsung}

Model 1

$A B N P R O D_{\text {it }}=\alpha_{0}+\alpha_{1}$ INTGORV $_{\text {it }}+\alpha_{2}$ INST $_{\text {it }}+\alpha_{4}$ COMP $_{\text {it }}+€_{\text {it }}$

Model 2

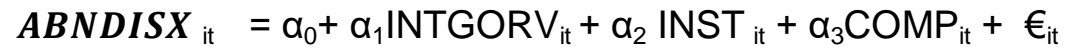

Model 3

$\boldsymbol{A B N C F O}_{\text {it }}=\alpha_{0}+\alpha_{1}$ INTGORV $_{\text {it }}+\alpha_{2}$ INST $_{\text {it }}+\alpha_{3}$ COMP $_{\text {it }}+\epsilon_{\text {it }}$ 
Tabel 4.13. Analisis Regresi

\begin{tabular}{|l|c|l|l|l|l|l|l|}
\hline \multicolumn{1}{|c|}{$\begin{array}{c}\text { Variabel } \\
\text { Independen }\end{array}$} & $\begin{array}{c}\text { Tanda } \\
\text { Predik } \\
\text { sian }\end{array}$ & $\begin{array}{c}\text { Model 1 } \\
\text { Koefesien } \\
\text { (p-value) }\end{array}$ & Sig. & \multicolumn{2}{c|}{$\begin{array}{c}\text { Model 2 } \\
\text { Koefesien } \\
\text { (p-value) }\end{array}$} & \multicolumn{4}{c|}{$\begin{array}{c}\text { Model 3 } \\
\text { Koefesien } \\
\text { (p-value) }\end{array}$} & Sig. \\
\hline $\begin{array}{l}\text { Internal } \\
\text { Governance }\end{array}$ & $(-)$ & $-0,010$ & 0,027 & $-0,83$ & 0,008 & $-0,001$ & 0,039 \\
\hline $\begin{array}{l}\text { Kepemilikan } \\
\text { Institusional }\end{array}$ & $(-)$ & 0,133 & 0,109 & $-2,478$ & 0,003 & 0,029 & 0,016 \\
\hline $\begin{array}{l}\text { Dewan Komisaris } \\
\text { Indepnden }\end{array}$ & $(-)$ & $-0,063$ & 0,085 & $-1,870$ & 0,278 & $-0,034$ & 0,161 \\
\hline $\mathrm{N}$ & & 984 & & 984 & & 984 & \\
\hline $\mathrm{R}^{2}$ & & 0,014 & & 0,020 & & 0,014 & \\
\hline Adj R2 & & 0,010 & & 0,017 & & 0,011 & \\
\hline F Value & & 3,432 & 5,878 & & 3,920 & \\
\hline
\end{tabular}

Sumber: data olahan SPSS

Tabel 4.13 menunjukkan bahwa internal governance berpengaruh negatif terhadap abnormal biaya produksi yang dilihat dari nilai koefesien $-0,010$ dan signifikan pada nilai $0,027<0,005$, sehingga hipotesis 1a diterima. Pengujian model 2 menunjukkan bahwa terdapat pengaruh negatif antara internal governance terhadap abnormal biaya diskresioner yang dilihat dari nilai koefesien $-0,83$ dan signifikan pada nilai $0,008<0,05$, sehingga hipotesis 1b diterima. Model 3 menunjukkan bahwa terdapat hubungan negatif antara internal governance dengan abnormal arus kas oprasi yang ditunjukkan dari nilai koefesien -0,001 dan signifikan dengan nilai $0,039<0,05$, sehingga hipotesis $1 \mathrm{C}$ diterima.

\section{Model dengan Variabel Kepemilikan Institusional Sebagai Pemoderasi}

\section{Model 4}

$\boldsymbol{A B N P R O D}{ }_{\text {it }}=\alpha_{0}+\alpha_{1}$ INTGORV $_{\text {it }}+\alpha_{2}$ INST $_{\text {it }}+\alpha_{3}$ COMP $_{\text {it }}+\alpha_{4}$ INST INTGORV $^{*} €_{\text {it }}$

\section{Model 5}

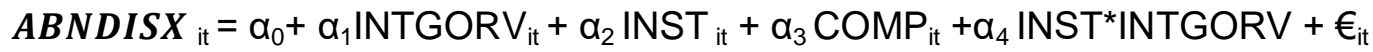

\section{Model 6}

$\boldsymbol{A B N C F O}$ it $=\alpha_{0}+\alpha_{1}$ INTGORV $_{\text {it }}+\alpha_{2}$ INST $_{\text {it }}+\alpha_{3}$ COMP $_{\text {it }}+\alpha_{4}$ INST INTGORV $^{*} \epsilon_{\text {it }}$

Tabel 4.14 menunjukkan hasil pengujian untuk model 4, yang menunjukkan bahwa kepemilikan institusional tidak dapat memperkuat pengaruh negatif antara internal governance terhadap abnormal biaya produksi yang ditunjukkan dengan nilai signifikan 0,464>0,05, sehingga hipotesis $\mathbf{2 a}$ tidak terdukung. Pengujian model 5 menujukkan bahwa kepemilikan institusional berhasil pemperkuat atau memodrasi pengaruh negatif antara internal governance terhadap abnormal biaya diskresioner yang ditunjukkan dari nilai koefesien -0,359 dan signifikan 0,001<0,05 dan terdapat peningkatan nilai adj $R^{2}$ dari 0,017 (model 2) menjadi 0,028 (model 5), sehingga dapat disimpulkan hipotesis $\mathbf{2 b}$ terdukung. Pengujian model 6 menujukkan bahwa kepemilikan institusional mampu memoderasi hubungan negatif antara internal governance terhadap abnormal arus kas operasi yang dilihat dari nilai koefesien -0,004 
dan signifikan pada nilai $0,042<0,05$, selain itu juga terdapat peningkatan nilai adj $R^{2}$ dari nilai 0,011 (model 3) menjadi 0,015 (model 6), sehingga dapat disimpulkan bahwa hipotesis 2c terdukung.

Tabel 4.14. Analisis Regresi

\begin{tabular}{|l|c|l|l|l|l|l|l|}
\hline \multicolumn{1}{|c}{$\begin{array}{c}\text { Variabel } \\
\text { Independen }\end{array}$} & $\begin{array}{c}\text { Tanda } \\
\text { Predik } \\
\text { sian }\end{array}$ & $\begin{array}{c}\text { Koefesien } \\
\text { (p-value) }\end{array}$ & Sig. & \multicolumn{2}{c|}{$\begin{array}{c}\text { Model 5 } \\
\text { Koefesien } \\
\text { (p-value) }\end{array}$} & \multicolumn{3}{c|}{$\begin{array}{c}\text { Model 6 } \\
\text { Koefesien } \\
\text { (p-value) }\end{array}$} & Sig. \\
\hline $\begin{array}{l}\text { Internal } \\
\text { Governance }\end{array}$ & $(-)$ & $-0,004$ & 0,638 & $-0,334$ & 0,000 & $-0,004$ & 0,006 \\
\hline $\begin{array}{l}\text { Kepemilikan } \\
\text { Institusional }\end{array}$ & $(-)$ & 0,279 & 0,196 & $-7,247$ & 0,000 & $-0,029$ & 0,352 \\
\hline $\begin{array}{l}\text { Dewan Komisaris } \\
\text { Independen }\end{array}$ & $(-)$ & $-0,302$ & 0,080 & $-1,345$ & 0,434 & $-0,028$ & 0,243 \\
\hline Inst_Intrgrov & $(-)$ & $-0,011$ & 0,464 & $-0,359$ & 0,001 & $-0,004$ & 0,042 \\
\hline $\mathrm{N}$ & & 984 & 984 & & 984 & \\
\hline $\mathrm{R}^{2}$ & & 0,015 & 0,033 & & 0,020 & \\
\hline Adj R2 & & 0,009 & & 0,028 & & 0,015 & \\
\hline $\mathrm{F}$ Value & & 2,706 & 7,161 & & 3,986 & \\
\hline
\end{tabular}

Sumber: data olahan SPSS

Model dengan Variabel Dewan Komisaris Independen Sebagai Pemoderasi

Model 7

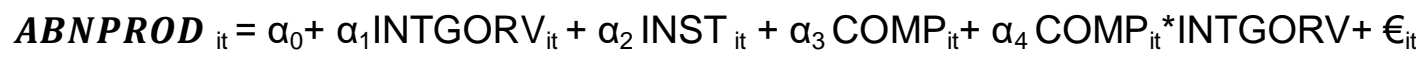

Model 8

$\boldsymbol{A B N D I S X _ { i t }}=\alpha_{0}+\alpha_{1}$ INTGORV $_{\text {it }}+\alpha_{2}$ INST $_{\text {it }}+\alpha_{4}$ COMP it $_{\text {it }}+\alpha_{4}$ COMP $_{\text {it }}{ }^{*} I N T G O R V+\epsilon_{\text {it }}$

Model 9

$\boldsymbol{A B N C F O}{ }_{\text {it }}=\alpha_{0}+\alpha_{1}$ INTGORV $_{\text {it }}+\alpha_{2}$ INST $_{\text {it }}+\alpha_{4}$ COMP $_{\text {it }}+\alpha_{4}$ COMP $_{\text {it }}{ }^{*} I N T G O R V+\epsilon_{i t}$

Tabel 4.15. Analisis Regresi

\begin{tabular}{|c|c|c|c|c|c|c|c|}
\hline \multirow{2}{*}{$\begin{array}{c}\text { Variabel } \\
\text { Independen }\end{array}$} & \multirow{2}{*}{$\begin{array}{c}\text { Tanda } \\
\text { Predik } \\
\text { sian }\end{array}$} & \multicolumn{2}{|c|}{ Model 7} & \multicolumn{2}{|c|}{ Model 8} & \multicolumn{2}{|c|}{ Model 9} \\
\hline & & $\begin{array}{l}\text { Koefe } \\
\text { sien } \\
(p- \\
\text { value) }\end{array}$ & Sig. & $\begin{array}{l}\text { Koefesien } \\
\text { (p-value) }\end{array}$ & Sig. & $\begin{array}{l}\text { Koefesien } \\
\text { (p-value) }\end{array}$ & Sig. \\
\hline $\begin{array}{l}\text { Internal } \\
\text { Governance }\end{array}$ & $(-)$ & $-0,031$ & 0,008 & $-0,161$ & 0,079 & 0,000 & 0,988 \\
\hline $\begin{array}{l}\text { Kepemilikan } \\
\text { Institusional }\end{array}$ & $(-)$ & 0,142 & 0,087 & $-2,428$ & 0,004 & 0,028 & 0,022 \\
\hline $\begin{array}{l}\text { Dewan Komisaris } \\
\text { Independen }\end{array}$ & $(-)$ & $-1,026$ & 0,012 & $-4,915$ & 0,195 & 0,103 & 0,863 \\
\hline Comp_Intrgrov & $(-)$ & $-0,050$ & 0,049 & 0,197 & 0,367 & $-0,003$ & 0,398 \\
\hline $\mathrm{N}$ & & 984 & & 984 & & 984 & \\
\hline$R^{2}$ & & 0,019 & & 0,021 & & 0,015 & \\
\hline Adj R2 & & 0,014 & & 0,017 & & 0,010 & \\
\hline F Value & & 3,552 & & 4,611 & & 3,118 & \\
\hline
\end{tabular}

Sumber: data olahan SPSS 
Tabel 4.15 menunjukkan hasil untuk pengujian model 7 , dimana hasil pengujian menujukkan bahwa dewan komisaris independen berhasil memoderasi pengaruh negatif antara internal governace terhadap abnormal biaya produksi dengan nilai koefesien negative $-0,05$, nilai signifikan 0,049<0,05 dan adanya kenaikan nilai adj $R^{2}$ dari 0,010 (model 1) menjadi 0,14, sehingga dapat disimpulkan bahwa hipotesis 3a terdukung. Pengujian untuk model 8 menunjukkan hasil bahwa dewan komisaris independen tidak mampu memoderasi hubungan antara internal governance terhadap abnormal biaya diskresioner, yang ditungjukan dengan nilai signifikan 0,367>0,005, sehingga hipotesis $\mathbf{3 b}$ tidak terdukung. Penggujian untuk model 9 menunjukkan hasil bahwa dewan komisaris independen tidak dapat memoderasi pengaruh antara internal governance terhadap abnormal arus kas operasi yang dilihat dari nilai signifikan $0,398>0,005$, sehingga hipotesis $3 c$ tidak terdukung

\section{Kesimpulan Hasil Pengujian Hipotesis}

$\begin{array}{llllll}\mathrm{H} 1 \mathrm{a} & \text { : Terdukung } & \mathrm{H} 2 \mathrm{a} & \text { : Tidak Terdukung } & \mathrm{H} 3 \mathrm{a} & \text { : Terdukung } \\ \mathrm{H} 1 \mathrm{~b} & \text { : Terdukung } & \mathrm{H} 2 \mathrm{~b} & \text { : Terdukung } & \mathrm{H} 3 \mathrm{~b} & \text { : Tidak Terdukung } \\ \mathrm{H} 1 \mathrm{c} & \text { : Terdukung } & \mathrm{H} 2 \mathrm{c} & \text { :Terdukung } & \mathrm{H} 3 \mathrm{c} & \text { :Tidak Terdukung }\end{array}$

\subsection{Pembahasan}

\subsubsection{Pengaruh Internal Governance terhadap Manipulasi Laba Rill}

Hasil pengujian menunjukkan bahwa internal governance berpengaruh signifikan negatif terhadap manipulasi laba rill yang dilakukan melalui (1) abnormal biaya produksi (2) abnormal biaya diskresioner dan (3) abnormal arus kas operasi. Hal ini menujukkan bahwa semakin tinggi efektifitas dari internal governance semakin rendah tindakan manajemen laba rill yang dilakukan manajemen. Dalam penelitian ini internal governance diukur dengan opportunity key subordinate executives, dan menunjukkan bahwa key subordinate executives yang memiliki peluang yang tinggi untuk menjadi CEO dimasa depan, akan menghindari tindakan manajemen laba rill dan dapat berfungsi sebagai kontrol atas tindakan oportunistik CEO.

Agency thory menyatakan bahwa terdapat perbedaan kepentingan antara manajer dan pemilik perusahaan dimana manajer dapat melakukan tidakan oportunistik yang menguntukan dirinya sendiri dan merugikan pemilik. Sejalan dengan teori tersebut mekanisme kontrol yang baik dapat menurunkan tindakan oportunistik tersebut, penelitian ini membuktikan bahwa internal governance dapat menjadi suatu media kontrol yang dapat menurunkan tidakan oportunistik seperti perekayasaan laba melalui manajemen laba aktivitas rill. Sehingga pertentangan kepentingan dan agency cost dapat diturunkan.

Key subordinate executives yang memiliki peluang untuk menjadi CEO kedepannya, akan berorientasi pada laba jangka panjang sehingga cenderung tidak akan terlibat pada 
aktivitas abnormal akrus kas oprasi seperti tindakan pemberian pinjaman lunak, diskon harga yang berlebihan untuk meningkatkan penjualan jangka pendek, namun dapat menimbulkan kerugian pada periode yang akan datang. Selain itu internal governance yang dilakukan key subordinate executives dapat mengkontrol tindakan abnormal biaya diskresioner yang menurukan biaya $R \& D$, biaya iklan dll, yang dapat menurunkan perluang menggungguli produk di pasar yang kompetitif. Penelitian ini sejalan dengan penelitian Chen et al. (2016) Landier et al., 2009 Acharya at al., 2011, yang menunjukkan adanya pengaruh signifikan antara internal governance terhadap manajemen laba rill.

\subsubsection{Pengaruh Kepemilikan Institusional, Internal Governance Terhadap Manajemen Laba Rill}

Hasil pengujian menunjukan bahwa kepemilikan institusional mampu memoderasi hubungan negatif antara internal governace terhadap manajemen laba rill. Tingginya proporsi saham yang dimiliki oleh institusi lain dapat menjalankan fungsi kontrol sehingga dapat memperkuat pengaruh internal governace untuk mengurangi perekayasaan laba yang dilakukan melalui manipulasi abnormal biaya arus kas operasi dan abnormal biaya dikresioner. Akan tetapi penelitian ini tidak berhasi membuktikan bahwa kepemilikan institusional dapat memperkuat pengaruh internal governance untuk mengurangi manajemen laba yang dilakukan melalui abnormal biaya produksi, hal ini kemungkinan disebabkan karena informasi dibidang produksi merupakan informasi yang kompleks dan sulit untuk dipahami oleh pihak eksternal, sehingga kepemilikan saham oleh institusi lain tidak dapat mempengaruhi kebijakan mengenai biaya produksi.

Penelitian ini sejalan dengan teori agensi yang menyatakan bahwa adanya kontrol dari pihak luar seperti kepemilikan instritusional dapat mengurangi kesempatan oportunistik yang mungkinsaja dapat dilakukan pihak manajemen atas pertentangan tujuan antara agen dan prinsipal. Seperti tindakan manipulasi laba aktivitas rill. Kontrol dari pihak internal dan eksternal (kepemilikan institusional) dapat mengurangi agency cost yang mungkin dapat timbul. Penelitian ini sejalan dengan penelitian terdahulu oleh Gumilang et al., (2015) yang menyatakan kepemilikan institusional dapat menjadi pihak yang mengawasi kinerja manajer dan mengurangi tindakan manipulasi laba aktivitas nyata perusahaan.

\subsubsection{Pengaruh Dewan Komisaris Independen dan Internal Governance Terhadap Manajemen Laba Rill}

Hasil penelitian ini menunjukkan bahwa dewan komisaris independen dapat memoderasi pengaruh negatif antara internal governance terhadap manajemen laba rill. Hal ini 
berarti bahwa dengan adanya dewan komisaris yang berasal dari luar perusahaan, atau adanya pengawasan dari pihak yang indepeneden dan kontrol dari internal governance dapat menurunkan kecenderungan tindakan oportunistik seperti manipulasi laba aktivitas rill. Namun pada penelitian ini hanya berhasil membuktikan bahwa dewan komisaris independen dapat mempengaruhi manajemen laba rill yang dilakukan melalui abnormal biaya produksi saja, sedangkan untuk abnormal biaya diskresioner dan abnormal arus kas operasi tidak terbukti. Hal ini dapat disebabkan karena sebagian besar dewan komisaris independen merupakan pihak yang memiliki kemampuan yang baik terkait dengan operasional perusahaan seperti produksi barang, pengetahuan tersebut dapat mengawasi tindakan manajemen seperti tindakan over production sehingga dapat menurunkan abnormal biaya produksi.

Dewan komisaris independen dapat menjadi pihak yang memberikan pengawasan yang lebih baik, karena dewan komisaris independen merupakan dewan komisaris yang bebas dari hubungan bisnis atau hubungan lainnya, sehingga tidak ada yang dapat mempengaruhi kemapuannya dalam bertindak secara independen atau bertindak semata-mata demi kepentingan independen (Efendi, 2016), sehingga dapat mengurangi konflik kepentingan dan dapat menurunkan agency cost.

\section{Kesimpulan, Keterbatasan, dan Saran}

\subsection{Kesimpulan}

Penelitian ini bertujuan untuk menguji apakah internal governance yang diukur dengan opportunity key subordinate executives dapat menurunkan tindakan perekayasaan laba melalui manajemen laba rill. Penelitian ini menggunakan seluruh perusahaan saham yang terdaftar di BEI yang telah memenuhi kriteria sampel. Penelitian ini berhasil memberikan bukti bahwa internal governance mampu menurunkan tindakan manipulatif laba yang dilakukan manjer atas. Selain itu penelitian ini juga memberikan dukungan bahwa kepemilikan institusional dan dewan komisaris independen dapat memoderasi pengaruh negatif antara internal governance dengan manajemen laba rill.

\subsection{Keterbatasan}

Terdapat beberapa keterbatasan dalam penelitian ini, yakni terdapat sejumlah perusahaan yang dikeluarkan dari pengujian. Hal tersebut disebabkan karena perusahaan tersebut tidak menjelaskan dalam laporan tahunan atau Web informasi terkait keterangan anggota key subordinate executives. Penelitian ini hanya menggunakan tiga tahun penelitian saja. Keefektifan internal governance hanya diukur dengan proxy opportunity of key subordinate 
executives saja. Manipulasi laba yang digunakan dalam penelitian ini hanya manajemen laba yang dilakukan melalui aktivitas rill saja, sedangkan manajemen laba akrual tidak diteliti dalam penelitian ini.

\subsection{Saran}

Berdasarkan hasil, pembahasan dan kesimpulan serta keterbatasan penelitian, maka dapat diberikan saran sebagai berikut; Penelitian selanjutnya dapat memperbandingkan pula pengaruh internal governance terhadap manajemen laba rill dengan manajemen laba akrual. Penelitian selanjutnya dapat memperluas sampel dengan memperbandingkan Negara Indonesia dengan Negara lainnya. Untuk menguji perbedaan keefektivan internal governance.

\section{Daftar Pustaka}

Clarkson, P.M.,dan G. Richardson. 2008. Revisiting the Relation Between Environmenttal Performance and Environmental Disclosure: An Empirical Analysis. Accounting, Organisations and Society33 (8): 303-327.

Cornett, 2006. Earnings Manajement, Corporate Governance, and True Financial Performance', Working Paper. Boston College, Chestnut Hill, New York.

Dechow, P.M, R.G. Sloan., dan A.P. Sweeney. 1996. Causes and Consequences of Earnings Manipulation: Analysis of Firms Subject to Enforcement Actions by The SEC, Contemporary Accounting Research 13 (2): 1-36.

Fama, E.F.,danM.C. Jensen. 1983. Separation of Ownership and Control.Journal of Law and Economics26 (3): 1-325.

Fombrun, C.J., N.A. Gardberg., dan J.M. Sever. 2000. The Reputation Quotient: A Multistakeholder Measure of Corporate Reputation. Journal of Brand Manajement 7 (4): 41 255.

Gelb, D.S., dan A. Strawser. 2001. Corporate Social Responsibility and Financial Disclosure: An Alterna tive Explanation for Increased Disclosure. Journal of Business Ethics. 33 (5): $1-13$.

Graves, S.B., dan S.A. Waddock. 1994. Institutional Owners and Corporate Social Performance.Academy of Manajement Journal37(4): 1034-46.

Gray, R. 2005. Taking A Long View on What We Now Know About Social and Environmental Accountability and Reporting. Electronic Journal of Radical Organisation Theory9 (3): 131.

Gregory, H.J. 2000. Corporate Governance and the Role of the Board of Directors. Egon Zhender International.

Ghozali, I. 2009. Aplikasi Multivariate dengan Program SPSS, Badan Penerbit Universitas Diponegoro. Semarang.

Hackston, D.,dan J. Milne. 1996. Some Determinants Of Social And Environmental Disclosures In New Zaeland Companies. Accounting, Auditingand Accountability Journal9 (1): 77108. 
Hermanto, W. 2013. Pengaruh Kepemilikan Institusional, Ukuran Perusahaan, Leverage terhadap Manajemen Laba (Studi Empiris pada Perusahaan Mnufaktur yang Terdaftar di BEI Tahun 2010-2013). Naskah publikasi Universitas Muhamadiah Surakarta.

Hong, Y., dan M.L. Andersen. 2011. The Relationship Between Corporate Social Responsibility and Earnings Manajement, An Exploratory Study.Journal of Business Ethics104 (4): 461- 471 .

Jaggi, B., S. Leung., dan F. Gul. 2009. Family Control, Board Independence and Earnings Manajement: Evidence Based on Hong Kong Firms. Journal Account Public Policy28 (3): 281-300.

Jensen, M.C.,dan W.H Meckling. 1976. Theory Of The Firm: Manager Behavior, Agency Cost and Ownership Structure. Journal of Financial Economics 3 (5): 305-360.

Jo, H., danA.M Harjoto. 2011. Corporate Governance and Firm Value: The Impact of Corporate Social Responsibility. Journal of Business Ethics 103 (3): 351-383.

Kim, Y., M.S Park, danB. Wier. 2012.Is Earnings Quality Associated with Corporate Social Responsibility?.The Accounting Review87 (3): 761-796.

Leuz, C., D. Nanda, dan P. Wysocki. 2003. Earnings Manajement and Investors Protection: An International Comparison. Journal of Financial Economics 69 (3): 505-527.

Patten, D.M.,dan G. Trompeter. 2003. Corporate Responses to Political Costs: An Examination of he Relation Between Environmental Disclosure and Earnings Manajement.Journal of Accounting and Public Policy 22 (2): 83-9.

Prior, D., J. Surroca., danJ.A Tribo. 2008. Are Socially Responsible Managers Really Ethical? Exploring the Relationship Between Earnings Manajement and Corporate Social Responsibility, Corporate Governance. An International Review(16) 3: 443-459.

Rice. 2013. Pengaruh Leverage, Kepemilikan Institusional, Ukuran dan Nilai Perusahaan terhadap Tindakan Manajemen Laba. Jurnal Wira Ekonomi Mikroskil (3)01: 41-50.

Scott, W.R. 2012. Financial Accounting Theory $6^{\text {th }}$ edition'. Toronto Pearson Education. Canada.

Shleifer, A.,dan R.W, Vishny. 1997. A Survey of Corporate Governance. Journal of Finance 52 (2): 737-783.

Shleifer, A. 2004. Does Competition Destroy Ethical Behavior?. Working Paper. Harvard University.

Sun, N., A. Salama., K. Hussainey., dan M. Habbash. 2010. Corporate Environmental Disclosure, Corporate Governance, and Earnings manajement. Managerial Auditing Journal25 (27): 679-700.

Young, W.O., Y.C Kyun., dan M. Aleksey. 2011.The Effect of Ownership Structure on Corporate Social Responsibility: Empirical Evidence from Korea. Journal of Business Ethics104 (3): 283-297.

Zahra, S.A., R.L Priem., danA.A Rasheed. 2005. The Antecedents and Consequences of Top Manajement Fraud. Journal of Manajement 31 (3): 803-28. 